\author{
Eklics Kata - Koppán Ágnes \\ Pécsi Tudományegyetem \\ kata.eklics@aok.pte.hu \\ akoppan@gmail.com
}

\title{
AZ ORVOSI KOMMUNIKÁCIÓS KÉSZSÉGEK FEJLESZTÉSÉNEK HATÉKONY MÓDJA: SZIMULÁCIÓS BETEGKIKÉRDEZÉS
}

\section{Bevezetés}

Az új évezred felsőoktatási kihívásai között különleges helyet foglal el az orvosi kommunikáció oktatása, hiszen az egészségügyi rendszer infrastrukturális, valamint a humán erőforrás hiányosságaiból adódó nehézségeinek csökkentésén túl a betegközpontú szemlélet kialakítása, továbbá az orvos és az együttműködő egészségügyi személyzet mentális egészségének megtartása is cél (W1). Ezért olyan képzési módszerek alkalmazása vált szükségszerủvé, amelyek hatékonyabban készítik fel a hallgatót a páciensekkel és munkatársaikkal történő interakciókra. E módszerek közé tartozik a szimulációs beteg-kikérdezés. A fentieken túl indokolja még a szimulációs képzés bevezetését az egyetemeken növekvő hallgatói létszám, a fokozódó szakorvoshiány, illetve a klinikán fekvő betegek állapota. A Pécsi Tudományegyetem Általános Orvostudományi Karán, 2016 őszén bevezetésre került az a szimulációs képzés, amelylyel hatékonyan fejleszthetők orvostanhallgatóink szakmai kommunikációs készségei. Helyzetgyakorlatok során a hallgatók kipróbálhatják, hogyan lehet kikérdezni a beteget korábbi betegségeiről, jelen panaszairól, milyen módon célszerủ a rossz hírt közölni különböző állapotú, szociokulturális hátterű páciensekkel, hogy lenne optimális a beteget vagy hozzátartozóját tájékoztatni, úgy, hogy a túlélési esélyei ne csökkenjenek. Mindezt anélkül tehetik meg, hogy a beteg akár érzelmi, akár fizikai károsodást szenvedne. A szakmai nyelvhasználattal együtt a szocio-kognitív és klinikai készségeik is fejlödnek.

\section{A valós betegek orvosi kommunikáció oktatásába történő bevonásának nehézségei}

Az orvosképzés alapjának tekintett betegkikérdezés gyakorlásának helyszíne hagyományosan a klinika. Mégis úgy véljük, hogy az anamnézisfelvétel sikeres elsajátítása kizárólag a kórházban fekvő, valós betegekkel több akadályba is ütközik. Betegjogi kérdéseket vethet fel az, ha a hallgatók magas létszáma és a viszonylagosan alacsony beteglétszám miatt egy beteget naponta többször kérdeznek ki, vagy a beteg állapotának nem kedvez 
a fizikális vizsgálathoz szükséges gyakori felültetés, beszélgetés. A gyakorlatvezető szakorvosok hiánya nem biztosítja a felügyeletet minden percben a kiscsoportos gyakorlatoknál, így előfordulhat, hogy a még bizonytalan hallgató érzelmi károkat okoz. Az egyéni kikérdezés lehetősége is korlátozott, hiszen magas a hallgatói létszám, ezzel szemben alacsony a beteglétszám.

\section{A szimulációs betegkikérdezés alapja}

Korábbi cikkünkben (Koppán et al. 2017) beszámoltunk arról, hogy a nyugati társadalmakban az orvosképzés szimulációs gyakorlataiba már a múlt század hatvanas éveiben megkezdődött a standardizált páciensek (SP) bevonása, ami a század vége felé vált gyakorlattá (Dietz 2006). Amerikai, német, ausztrál, brit egyetemeken meghatározó ezen betegek alkalmazása, akik laikusok vagy színészek, és egy felkészítő tréning által képessé válnak arra, hogy betegeket alakítsanak, betegségük tüneteiről beszámoljanak. A háttérben lehet valamilyen betegségük, kórelőzményük természetesen, de ez nem alapfeltétele kiválasztásuknak (Nestel et al. 2011).

Az SP-programokat elemző kutatások között többször találkozunk a standardizált és a szimulált beteg szóhasználattal, néhol szinonimaként, másutt eltérő fogalmakként. Jelen tanulmányunkban Beigzadeh és munkatársai (2016) nyomán elkülönítjük a kettőt. A standardizált beteg olyan egészséges vagy bizonyos betegséggel kezelt laikus személy, aki elsajátít egy páciensszerepet, megtanulja azokat a tüneteket, viselkedési mintázatokat, amelyek az adott betegségre jellemzőek, és a helyzetgyakorlat során módosítások nélkül tud válaszolni az orvostanhallgatók kérdéseire. Itt hangsúlyozandó, hogy a standardizált beteg nem professzionális színész. A szimulált páciens azonban színészi képességekkel rendelkező laikus vagy színész, aki autentikus módon képes szimulálni (előzetes felkészítés után) bármilyen betegséget. Ellentétben a standardizált beteggel, a szimulált beteg improvizálhat, kiegészítheti, módosíthatja a megadott kerettörténetet, valamint olyan érzelmi telítettséggel teheti életszerủvé a szituációt, amely erősebb válaszreakciót provokál a gyakorló orvostanhallgatóban (Beigzadeh et al. 2016).

Számos amerikai egyetem állandó standardizált betegeket alkalmaz, akik különböző etnikumú, iskolázottságú, társadalmi, gazdasági, kulturális háttérrel rendelkeznek. Speciális esetekben színészeket hívnak meg, hogy csatlakozzanak a programhoz, főleg az érzelmileg nehezen kezelhető szituációk gyakoroltatására. A klasszikus SP-modulokban a felkészítés jól kidolgozott szempontrendszer alapján történik, a standardizált betegeknek minden fontos információt meg kell tanulniuk az eljátszandó betegségekről, valamint a beteg személyiségéről (Dietz 2006).

\subsection{Szimulációs betegkikérdezés: szimulált vagy standardizált pácienssel?}

Programunk kialakításakor hosszas kutatómunkába fogtunk, hogy feltárjuk, vajon a standardizált vagy a szimulált beteg képes hathatós módon fejleszteni leendő 
orvosaink klinikai készségeit, különös tekintettel a szakmai kommunikációs készségekre, empátiára. Viret és munkatársai (2016) hallgatói értékelések alapján vetették össze a színész és a laikus standardizált beteg szerepalakítását. Ott közös SP-tréningen vett részt a két csoport, s maguk a résztvevők sem tudták egymásról, hogy közülük ki színész, ki nem. A képzés vezetői pozitív visszajelzéseket kaptak, mivel a profeszszionális és a laikus leendő „páciensek” olyan információkhoz jutottak, olyan készségeik fejlődtek, amelyek segítségével képessé váltak például egy mellkasi fájdalommal kórházba szállított beteg alakítására. Ezáltal az anamnézisfelvétel szerkezetének, kérdéstechnikájának begyakoroltatása az orvostanhallgatókkal könnyen kivitelezhetővé vált. A hallgatók hasonlóan ítélték meg a színészek és a laikusok szerepalakításait. A beteget alakítók teljesítményében nem láttak jelentős különbséget sem az életszerűség, sem a természetesség, sem az ismételhetőség terén. Ez a tanulmány azt a megközelítést sugallja, hogy megfelelő volna a laikusok bevonása a programba, mindaddig, amíg a színészek hatékonyságát vizsgáló kérdésre adott válaszok elemzését olvashatjuk. Ez ugyanis hangsúlyozza, hogy az orvostanhallgatók információszerző stratégiáit jobban kellett aktiválni a színészekkel folytatott beszélgetésekben (akik teljes átéléssel alakították a magába forduló, halk szavú, dühös, kiabáló, sokat beszélő, nehéz pácienst), minden információért keményen meg kellett dolgozniuk.

A színész és a tapasztalt beteg oktatásba való bevonásának előnyeit vizsgálja Bates is (2017). Tanulmányában a színész mint szimulált páciens szerepel, a tapasztalt beteg pedig egy olyan személy, akinek kórtörténetében fellelhető az adott betegség. Vélekedésében a betegség átélése meghatározó szempont, nem megtanulható; egy potenciális forrás, amely a tapasztalt beteget képessé teszi arra, hogy reagáljon a váratlan kérdésekre, pillanatokra. Ezen túlmenően fogyatékossággal, beszédproblémákkal is rendelkezhet a beteg, ami kimozdíthatja az orvostanhallgatót a gyakorló szituációból, és inkább a terápiás cél felé motiválhatja, sikeresen aktiválva az orvostanhallgató empátiáját. Bármilyen hasznosnak is tűnhet a valós fizikai fogyatékossággal élők integrálása a programba, hátrányként hangsúlyozandó az az érzelmi sérülékenység, amelynek több hallgatói csoport előtt lesz kitéve, miközben felidézi a régi kiváltó eseményt; emellett ezen betegek felkészítési ideje is hosszabb.

A fenitek alapján úgy véljük, hogy az ismételhetőség és pontosság jegyében célszerű a professzionális színészek alkalmazása a szimulációs gyakorlatok során - a számos újra ismételt jelenet által -, hogy a programban részt vevő minden orvostanhallgató azonos tapasztalatot szerezhessen, ugyanakkor életszerủ szituációban vehessen részt, amelyet spontán reakcióikkal a színészek hoznak létre. A spontaneitás mellett a színészek érzéke a drámai légkör megteremtésére egy érzelmileg telített szituációban olyan motivációs értékkel bír, amely a hallgatókat a szituációban való teljes szerepazonosulásra ösztönzi (Owen 2018). A felfokozott érzelmi involváltság (például sírás, dühroham, félelem, egy hozzátartozó elvesztése okozta elkeseredés, szomorúság) és a hallgatók még alakuló, olykor bizonytalan, esetleg helytelen reakciója nem okoz maradandó lelki sérülést a színész páciensekben. 
A bizalmas információ kezelése sem jelenik meg problémaként a hallgatók számára ezen a szinten, mivel a színészek nem a saját betegségüket jelenítik meg.

A szimulált színész páciensek alkalmazása lehetővé teszi a strukturált értékelést. Mivel a kurzuson kiscsoportos betegkikérdezés történik, lehetőség nyílik arra, hogy a hallgatók is megfigyeljék a dialógust, azt követően ők is visszajelzést adjanak. Az interjúk apró részletének elemzésére lehetőség adódik, ez sajnos nem tud teljes mértékben megvalósulni a betegágy mellett, a klinikán. A körülmények a MediSkillsLabben nyugodtabbak, valós szobatársak, valós hozzátartozók, ápolók nem zavarják a beszélgetést. Ha szükséges, a beszélgetés megszakítható, a jelenlevő szakorvos instrukciói alapján bizonyos részei újrapróbálhatók, gyakorolhatók, ami valódi betegekkel nem lenne lehetséges. A beszélgetésekről a rejtett kamerás felvételek készülnek, melyek az interakciók intimitását nem zavarják. A felvételek azután kiértékelhetők, a későbbiekben az oktatásban felhasználhatók.

\section{Módszer: a szimulációs gyakorlat menete}

A szimulált páciensek egy többlépcsős előkészítő munka után kerülnek a programba (Koppán et al. 2017). Elsőként a velünk együttműködő klinikusok autentikus eseteket gyüjtenek mindennapi gyakorlatukból, amelyek átdolgozással - pszichiáter, nyelvész, majd ismét a klinikus szakmai kontrollja után - betegprofilokká változnak, ezeket tanulják meg a színészek. Az órákon legtöbbször klinikai betegágy melletti jelenetet szimuláló betegkikérdezés, anamnézisfelvétel történik, ahol az orvostanhallgató az orvos, a színész a páciens, a hozzátartozó vagy egy kolléga. Mindez az adott esettől függően kiegészülhet más szakmai kommunikációs feladatokkal. Így például konfliktuskezeléssel (orvos és beteg, orvos és személyzet, orvos és hozzátartozó között), meggyőzéssel (pl. szakmai érvek felsorakoztatásával, a beteg tájékoztatásával egy sebészeti beavatkozásról, figyelmének felkeltésével az adott egészségügyi állapotának súlyosságára vonatkozóan, majd megfontolt döntéshozatal elősegítésével (Kuna 2019), továbbá rossz hír közlésével. Az interperszonális kommunikációs szituációban létrejövő szerep- és hatalmi viszonyok értelmezése külön figyelmet kap a megszólítások gyakoroltatásakor (Csiszárik-Domonkosi 2018).

A klinikai jelenetet szimuláló helyzetgyakorlat lehetővé teszi továbbá a beszélők közötti kapcsolat megfigyelését, a barátságosság, a közvetlenség, a hivatalosabb távolságtartás, a tiszteletadás, a hierarchia, az együttérzés verbális és non-, illetve paraverbális jeleinek tudatosítását (Bartha-Hámori 2010; Kárpáti 2018). Az interjút követően az orvostanhallgató esetismertetést ad az adott eset szakterületét képviselő rezidensnek, illetve szakorvosnak. Ezt már szaknyelvi kódváltással teszi; a betegkikérdezés laikusok által érthető mindennapi szóhasználata átváltozik orvosi terminusokkal gazdagított, tömörített szaknyelvvé. Ezután a szituáció három szempontú értékelése történik: színész-páciens, orvos-instruktor, kommunikációs instruktor ad visszajelzést a hallgatónak teljesítményéről. Az életszerű környezetet a szimulációs oktatásiközpont, a MediSkillsLab biztosítja. 


\section{Szükséges szakmai kompetenciák}

A fentebb ismertetett szimulációs betegkikérdezés kiváló alkalmat biztosít a leendő orvosok szakmai és szaknyelvi kompetenciáinak fejlesztésére. Hogy pontosan tudjuk, melyek ezek a kompetenciák, röviden ismertetjük az egészségügyben dolgozók számára összeállított szükséges szakmai kompetenciák listáját, amelyet az amerikai Orvosi Intézet (Institute of Medicine) ajánlásából vettünk át (Greinern-Knebel 2003).

5.1. Betegközpontú ellátás biztositása: a betegek különbözőségének, értékrendjének, preferenciáinak és kifejezett szükségleteinek felismerése, elfogadása és biztosítása; a fájdalom és szenvedés enyhítése; a folyamatos ellátás/ápolás megszervezése; a betegek meghallgatása, tájékoztatása, edukálása és velük való kommunikáció; közös döntéshozatal és kezelésterv; a betegségmegelőzés és a wellness folyamatos hangsúlyozása, az egészséges életstílus népszerüsítése.

5.2. Interdiszciplináris csapatmunka: együttmüködés, kommunikáció és törődés összehangolása a folyamatos és megbízható ellátás érdekében.

5.3. Bizonyitékalapú gyakorlat megvalósitása: az optimális ellátás céljából jó kutatások beépítése a klinikai gyakorlatba és a betegek értékrendjébe, a megvalósítható mértékben képzésekben és kutatási tevékenységben való részvétel.

5.4. Minöségfejlesztés: hibák és veszélyek felismerése az ellátás során; alapvető biztonsági irányelvek megértése és alkalmazása, mint pl. standardizáció és egyszerűsítés; struktúra, eljárás és kimenet szempontjából a minőségi ellátás mérése és megértése, a beteg és a közössége szükségleteinek viszonyában; beavatkozások tervezése, tesztelése az ellátás rendszerének és eljárásainak megváltoztatására a minőségjavítás céljából.

5.5. Informatika felhasználása: kommunikáció, tudásmenedzselés, hibaminimalizáció és döntéshozatal IT segítségével.

$\mathrm{Az}$ öt kulcskompetencia megértéséhez, elsajátításához elengedhetetlen a szaknyelvi kompetencia, így annak fejlesztése kiemelkedő fontosságú. Kurzusunk során az első három kompetencia kap meghatározó figyelmet.

\section{Szakmai, szaknyelvi kompetenciafejlesztő lépések a kurzusvégi értékelések fényében}

Az elmúlt három év gyakorlata alapján kijelenthetjük, hogy a szemeszter során a hallgatók jelentős fejlődést mutatnak, magabiztosabbá és tudatosabbá válnak. A betegközpontú ellátáshoz szükséges szemlélet kialakítása érdekében olyan forgatókönyveket választottunk, amelyek a hallgatókat arra ösztönözték, hogy fogadják el a pácienseik igényeit: 
pl. amikor a daganatos beteg elzárkózik a kemoterápiától, az orvostanhallgató megpróbálja kideríteni az okát, majd más, hasonlóan hatékony kezelési módot javasol, például immunterápiát. Természetesen csak azokban az esetekben tehet így, amikor szakmai szempontból ez jó választás. Ha nem ért egyet a beteggel, a beteg empatikus meghallgatásával, majd kérdésekkel, később a meggyőzés eszközeivel kísérli meg a páciens igényeinek figyelembevételével módosítani a döntését.

Külön feladatként határoztuk meg a rossz hír közlését magába foglaló diagnózis ismertetését a beteggel. Ehhez minden hallgatónak egy betegség kiválasztása után fel kell készülnie annak tünetegyütteséből, a diagnózishoz szükséges vizsgálatokból, értékek értelmezéséből, valamint terápiás lehetőségekből, illetve a betegség lefolyásából, végkimenetéből. Majd a szemeszter során egy választott időpontban a kijelölt nő vagy férfi színész pácienssel kellett a diagnózist közölnie, aki improvizálva reagált, tetszőleges érzelmi reakciót produkált. Az orvostanhallgatónak feladata volt az érzelmi megnyilvánulások kezelése, a kétségbeesés, a fájdalom, a szomorúság enyhítése.

Az interdiszciplináris csapatmunkát elősegítendő kiscsoportos betegkikérdezéseket terveztünk. A valódi csapatmunka megvalósulása több órát vett igénybe, de a kurzuszáró betegkikérdezés idejére a munkamegosztás már szervezetté vált; egy-két hallgató jegyzetelt, a többiek kikérdezték a beteget a jelen panaszokról a kurzus elején ismertetett struktúra alapján: a fájdalomanamnézis kérdéseit követően kérdéseket tettek fel korábbi operációkról, az életmódból adódó és családi rizikófaktorokról, gyógyszerekről. Minden kiscsoportban megjelent egy vezető egyéniség, az ő vezetői tulajdonságaik a kikérdezés közben is megmutatkoztak, verbalizálódtak. A szóátvétel professzionálisabbá vált: az egymás szavába vágás helyett a rövid szünetek adta lehetőséget kihasználva határozottabb fogalmazást hallhattunk, pl.: Kollégám az imént kérdezte önt a lázáról. Hadd kérdezzem, mennyi volt a legmagasabb érték? Hol mérteltetszett mérni?

A hallgatói esetismertetés pontosabbá, szabatosabbá vált. Ez főként azokra a hallgatókra vonatkozik, akik mélyebb szakmai tudással rendelkeznek, illetve motiváltabbak a klinikai szakorvosok közötti nyelvhasználat elsajátítására. Hangsúlyozandó, hogy programunk elsődleges célja az orvos-beteg interakcióhoz szükséges kompetenciák fejlesztése, így nem tekintjük feladatunknak az esetismertetéshez szükséges kódolt nyelv tökéletes elsajátíttatását.

Az érzelmileg telített szimulációs gyakorlatok során - pl. halálhír közlése a hozzátartozóval - a hallgatók jelentős fejlődése érhető tetten empátiájuk kifejezésében. A szemkontaktus fenntartása, a megfelelő idő rászánása az információadásra, a személyközi tér gondos megválasztása, az érintés, a szükséges szünet megadása mind az empátia nonverbális jeleiként értelmezhetők. Az empátia megfigyelt nyelvi megnyilvánulásai, pl.:

- Látom, érzékenyen érinti a szituáció.

- Rosszul érinti, hogy sokan vagyunk.

- Megértjük, hogy nehéz.

- Nyugodjon meg, kérem! 
- Segithetek valamiben?

- Végigkisérem a kezelés során, bármilyen kérdése van, fordulhat hozzám e-mailben vagy személyesen is.

A beteginterjú kérdéstechnikáit gyakoroltatva szakmai vitába ütköztünk a nyitott vagy zárt kérdések feltevésével kapcsolatban. Szakorvosaink húsz-harminc év gyakorlata alapján kijelentették, hogy kulturálisan a magyar betegekkel a nyitott kérdések nem célravezetők. A beszélgetés kezdetekor, a jelen panaszok felvételekor a nyitott kérdés indokolt lehet ugyan, de a későbbiekben zárt kérdésfeltevéssel jobban kell irányítani a páciens figyelmét. Vagyis:

Elöször hagyjuk a beteget beszélni, pl. Tessék mondani, miért van most kórházban? Ezután strukturáltabban kérdezzünk, pl. Mikor kezdödött a fejfájás?

A hallgatók visszajelzései a színész páciensekkel való munka motivációs erejét hangsúlyozták, ezt a kurzuszáró visszajelzések is bizonyítják. További megerősítést kaptunk az általunk választott oktatási módszer fontosságáról, ugyanis a hallgatók szerint ezt nem lehet könyvből megtanulni.

\section{7. Összegzés}

A szimulációs orvos-beteg interakció komplexitása révén alkalmas a szaknyelvi kompetenciák fejlesztésére, például a megfelelő megszólítás, információszerzés, tájékoztatás, meggyőzés, rossz hír közlése egy szituációban kerül gyakoroltatásra. A szituációk reprodukálhatóságát, az érzelmi megnyilvánulások előfordulását a hivatásos színészek biztosítják. A tanulási folyamat motivációját a színész, az orvos és a kommunikációs instruktor együttműködése biztosítja. A szimulált pácienssel történő beszélgetés életszerű, ugyanakkor biztonságos környezetben történik, amely károkozás nélkül teszi lehetővé az empatikus, beteg-centrikus kommunikációs készségek fejlesztését.

A szimulációs központ által biztosított archiválhatóság, kiértékelhetőség egyénre szabott fejlesztési lehetőséget, hallgatócentrikus képzés lehetőségét rejti. A klinikusok által gyűjtött esetek eltérő etnikumú betegek bevonásával elősegíthetik a különböző kultúrák iránti érzékenyítést.

\section{Irodalom}

Bartha Csilla - Hámori Ágnes 2010. Stílus a szociolingvisztikában, stílus a diskurzusban. Magyar Nyelvör 134/3: 298-321.

Bates, Peter 2017. How to choose between an actor (or simulated patient) and an expert by experience. Voice study. https://peterbates.org.uk/wp-content/uploads/2017/10/How-tochoose-between-an-actor-and-an-expert-by-experience.pdf. (2018. 08. 18.) 
Beigzadeh, Amin - Bahmanbijari, Bahare - Sharifpoor, Elham - Rahimi, Mohammad 2016. Standardized patients versus simulated patients in medical education: are they the same or different. Journal of Emergency Practice and Trauma 2/1: 25-28. https://doi.org/10.15171/jept.2015.05

Csiszárik Katalin - Domonkosi Ágnes 2018. A gyógyító-beteg viszonylat megszólítási változatai egy mozgásszervi rehabilitációs osztály gyakorlatközösségében. Acta Universitas De Carolo Eszterházy Nominatae. Sectio Lingustica Hungarica XLIV: 109-128.

Dietz, Claire 2006. Performing as patients: Acting talents helpful in Standardized Patient Program. UW News. october 12. http://www.washington.edu/news/2006/10/12/perfor ming-as-patients-acting-talents-helpful-in-standardized-patient-program/ (2018. 08. 18.)

Greinern, Ann C. - Knebel, Elisa (eds.) 2003. Health Professions Education: A Bridge to Quality. Washington, DC: The National Academies Press.

Kárpáti Eszter 2018. Az orvosról alkotott kép. In: Dombi Judit - Farkas Judit - Gúti Erika (szerk.): Aszimmetrikus kommunikáció - aszimmetrikus viszonyok. Bicske: SZAK Kiadó. 846 -863.

Koppán Ágnes - Eklicsné Lepenye Katalin - Halász Renáta - Sebők Judit - Szemán Eszter - Németh Zsuzsanna - Rendeki Szilárd 2017. A színész mint szimulált páciens az oktatásban a Pécsi Tudományegyetem Általános Orvostudományi Karán. Orvosi Hetilap 158/26: 1038-1043. https://doi.org/10.1556/650.2017.30780

Kuna Ágnes 2019. Nyelv, meggyözés, gyógyitás. A meggyözés nyelvi mintázatai a 16-17. századi orvosi receptben. Segédkönyvek a nyelvészet tanulmányozásához 210. Budapest: Tinta Könyvkiadó.

Nestel, Debre - Tabak, Diana - Tierney, Tanya - Layat-Burn, Carine - Robb, Anja - Clark, Susan - Morrison, Tracy - Jones, Norma - Ellis, Rachel - Smith, Cathy - McNaughton, Nancy - Knickle, Kerry- Higham, Jenny - Kneebone, Roger 2011. Key challenges in simulated patient programs: An international comparative case study. BMC Medical Education 11/69. https://doi.org/10.1186/1472-6920-11-69

Owen, David 2018. Standardized patients and the art of maladies. The New Yorker. 8 January. https://www.newyorker.com/magazine/2018/01/08/standardized-patients-and-the-artof-medical-maladies (2018. 08. 19.)

Viret, Francine - Vadot, Sara - Morend, Laura - Christen, Ariane - Bonvin, Raphael 2016. Working with actors and non-actors as simulated patients: An advantage? MedEdPublish 5. https://doi.org/10.15694/mep.2016.000061

\section{Internetes hivatkozások}

W1 = Boissy, Adrienne Can empathy help us heal health care? TED-elöadás. https://www. ted.com/talks/adrienne_boissy_can_empathy_help_us_heal_health_care(2019.04.12.) 